\title{
Preference and development of Tribolium castaneum (Herbst, 1797) (Coleoptera: Tenebrionidae) in whole grain and flour form of five corn varieties
}

\author{
LUDJI PANTJA ASTUTI", YUNITA EKA LESTARI, RINA RACHMAWATI, MUTALA'LIAH \\ Department of Plant Pests and Diseases, Faculty of Agriculture, Universitas Brawijaya. Jl. Veteran, Malang 65145, East Java, Indonesia. \\ Tel.: +62-341-575843, ’email: ludji_pa@ub.ac.id
}

Manuscript received: 5 November 2019. Revision accepted: 16 January 2020

\begin{abstract}
Astuti LP, Lestari YA, Rachmawati R, Mutala'liah. 2020. Preference and development of Tribolium castaneum (Herbst, 1797) (Coleoptera: Tenebrionidae) on whole grain and flour form of five corn varieties. Biodiversitas 21: 564-569. Red flour beetle can cause detrimental loss on stored corn during storage period. The usual forms of stored corn are whole grain and flour form. However, the information about the infestation on both form of stored corn is limited, therefore this research aims to investigate the feeding preference and development of Tribolium castaneum on various corn varieties (Pioneer 21, Pioneer 29, Pertiwi 3, Bisi 18, and Bisma) in whole grain and flour form. The research was conducted on Plant Pest Laboratory, Department of Plant Pests and Diseases, University of Brawijaya from February until March 2016. The feeds for treatment were Pioneer 21, Pioneer 29, Pertiwi 3, Bisi 18, and Bisma in whole grain and flour form. The observed variables were the adult presence, adult mortality, the number of eggs, larvae, pupae, F1 progeny emerged, the developmental period of eggs, larvae, and pupae, egg-adult, and life cycle. Data analyzed by ANOVA and followed by LSD at 5\%. The results showed that T. castaneum was more preferred to colonize and oviposition in Pioneer 21 flour than others i.e. 13.33 adults and 145 eggs. Similarly, on the population growth of T. castaneum, the highest number of eggs, larvae, pupae, and F1 progeny emerged was on Pioneer 21 flour i.e. 196 eggs, 179.67 larvae, 83.67 pupae, and 73.33 adults, respectively. Moreover, the fastest developmental period of egg, larva, and pupa, egg-adult and life cycle was also in Pioneer 21 flour i.e., 5.5, 26.77, 5.97, 38.23, and 41.87 days, respectively. Pioneer 21 corn variety has high protein content, therefore it is suitable for $T$. castaneum development.
\end{abstract}

Keywords: Corn varieties, development, preference, red flour beetle

\section{INTRODUCTION}

Corn is the second most important commodity after rice in Indonesia. While in the world, it is the third major cereal that cultivated after wheat and rice. It is originated from South and Central America (Oladejo and Adetunji 2012). Corn can be used as food $(48.4 \%)$, feed $(38.3 \%)$, industrial materials (6.2\%), and seeds (1.2\%) (Swastika et al. 2004). In Indonesia, corn is one of the staple food which has rich starch content, vitamins, proteins, and mineral (Khawar et al. 2007). The need for corn as food and feed is increasing by the year along with Indonesian population growth. Based on Statistics Indonesia (2019), corn production in 2015 was 20.67 million tons of dry shelled and increased by 1.66 million tons $(8.72 \%)$ than in 2014. Another increasing was happened in Indonesian feed mills at about $3.2 \%$ from 24.7 to 25.5 million tons in 2018 (McDonald and Meylinah 2019). The escalation of corn production must be followed by appropriate postharvest handling activities. Due to the corn production demand, there are many varieties of corn that are traded in Indonesia, such as Pioneer 21, Pioneer 29, Pertiwi 3, Bisi 18, and Bisma.

The vulnerable period of stored product is during the storage that can cause detrimental loss in both quantity and quality. Pest attacking stored products can cause 20-30\% losses in tropical countries (Suleiman and Kurt 2015). Red flour beetle, Tribolium castaneum (Herbst, 1797)
(Coleoptera: Tenebrionidae) is one of the stored product pests that can cause losses a wide range of durable stored products including barley, corn, flour, millet, wheat, potatoes, sweet potatoes, dried fruit, nut, and sorghum (Bennet 2003). This species is an important and cosmopolitan insect pest on grain processing and storage (Fedina and Lewis 2007). T. castaneum can be a major pest on flour mills, stored biscuit industry, and retail stores (Campbell and Hagstrum 2002). This pest causes more serious damage to the processed cereals in the form of flour rather than whole-grain (Zakka et al. 2013). The infestation of this insect cause unpleasant smell due to the benzoquinone secretion from its abdominal gland (Campbell and Runnion 2003).

Information on $T$. castaneum that attack corn varieties in the form of whole grain is limited, because of this pest generally feeds on broken grain as a secondary attack resulting from another pest. Even though, the stored corn is not only stored in the form of whole-grain but also flour form. Furthermore, each corn varieties has different nutrition content and hardness level that could be the influence factor of its resistance. Hence, this research aimed to examine the preference, population growth, and development of $T$. castaneum on various varieties of corn, i.e., Pioneer 21, Pioneer 29, Pertiwi 3, Bisi 18, and Bisma in the form of whole grain and flour. 


\section{MATERIALS AND METHODS}

This research was conducted in Plant Pest Laboratory, Department Plant Pests and Diseases, Faculty of Agriculture, University of Brawijaya under laboratory condition $\left(27 \pm 2{ }^{\circ} \mathrm{C}\right.$, RH $\left.65 \pm 5 \%\right)$. T. castaneum were obtained from the warehouse in the market and have been reared in the laboratory for two generations. These insects were re-reared on separate glass jar for about a month that will be used for treatment. One hundred unsexed $T$. castaneum adults were put in glass jar $(\varnothing=15 \mathrm{~cm}, \mathrm{t}=17$ $\mathrm{cm}$ ) containing mix of wheat flour and: baker's yeast at a ratio (95\%: $5 \%$ ) for 7 days. Yeast addition on the feed was aimed to enrich the nutrition content of feed. Sex differentiate was carried on the pupae stage by distinguishing genital papillae of insects (Beeman et al. 2019), then insect rearing was continued in a different glass jar until adults emerged. Tested adult insects used on this treatment were 7-14 days old (Heinrichs et al.1985). Proximate analysis and hardness levels of feed were done to support the results research.

Research was consist of two experiments: (i) preference (ii) population growth and development of $T$. castaneum on five corn varieties in whole grain and flour form. These research used ten treatments (Pioneer 21 whole grain, Pioneer 29 whole grain, Pertiwi 3 whole grain, Bisi 18 whole grain, Bisma whole grain, Pioneer 21 flour, Pioneer 29 flour, Pertiwi 3 flour, Bisi 18 flour, and Bisma flour) and three replications arranged by Complete Randomized Designed. The preference test was done by free choice test method using preference cage $(\varnothing=28 \mathrm{~cm}, \mathrm{t}=8 \mathrm{~cm})$ consist of 10 rooms to investigate feeding and oviposition preference of adult insects. Thirty g of feed was put into each room in the preference cage, and 30 paired of adult insects were infested on the center of preference cage for 7 days and separately taken out depending on the chosen feed. The observed variables were the presence of adult insects and the number of eggs. The eggs laid on feed was taken by 50 mesh sieve. The adult male of $T$. castaneum is characterized by having small sex patches on the first pair of femur (Beeman et al. 2019).

Population growth and development test were done by no choice test method i.e. tested singly on each feed in different glass jar. Fifteen pairs of adult insects were put on the $30 \mathrm{~g}$ of feed-in glass jar $(\varnothing=6.5 \mathrm{~cm}, \mathrm{t}=9 \mathrm{~cm})$ covered by gauze for 7 days. The observed variables for population growth were adults mortality, the number of eggs, larvae, pupae, and F1 progeny emerged, while for insect development were egg, larva, pupa period, egg-adult, and life cycle of $T$. castaneum. Insect mortality and egg calculation were observed on 7 days after infestation then the feed and eggs were put back into the glass jar to be reared until the larvae, pupae, and F1 progeny emerged. Larvae and pupae of $T$. castaneum were observed on 14 and 28 days after infestation, respectively (Kayode et al. 2014). The observation of F1 progeny emerged was carried on every day since the first emerged until no more adults appeared. Egg-adult period was determined by calculating total development time of $T$. castaneum from egg until F1 progeny emerged, while life cycle was determined by calculating insect longevity and first oviposition time. Data were analyzed using analysis of variance (ANOVA) at 5\% and followed by least significant different (LSD) test at 5\% for further analyses. Analysis of data used R 3.5.2 software.

\section{RESULTS AND DISCUSSION}

\section{Colonization and oviposition preference of Tribolium castaneum on five corn varieties}

Insect preference had a certain response to the type and form of feed that can optimally support insect growth and development. In general, $T$. castaneum was preferred on flour form than whole grain in the same variety. This was in line with $T$. castaneum feeding behavior, which was categorized as a secondary pest (Rees 2004). Preference of $T$. castaneum both colonization and oviposition preference was significantly influenced by corn variety and form of the feed.

Tabel 1. Colonization preference of Tribolium castaneum on five corn varieties in whole grain and flour form

\begin{tabular}{|c|c|c|}
\hline \multirow{2}{*}{ Treatments } & \multicolumn{2}{|c|}{$\begin{array}{c}\text { Collonization preference ( } \bar{X} \pm \\
\text { SE) }\end{array}$} \\
\hline & Female (adult) & $\begin{array}{l}\text { Male + female } \\
\quad \text { (adult) }\end{array}$ \\
\hline Pioneer 21 whole grain & $1.00 \pm 0.00 \mathrm{a}$ & $3.67 \pm 0.19 \mathrm{a}$ \\
\hline Pioneer 29 whole grain & $1.33 \pm 0.19 b$ & $2.67 \pm 0.19 a$ \\
\hline Pertiwi 3 whole grain & $1.33 \pm 0.19 b$ & $2.67 \pm 0.38 \mathrm{a}$ \\
\hline Bisi 18 whole grain & $1.33 \pm 0.19 b$ & $3.00 \pm 0.33 a$ \\
\hline Bisma whole grain & $1.33 \pm 0.19 b$ & $3.33 \pm 0.38 \mathrm{a}$ \\
\hline Pioneer 21 flour & $8.00 \pm 0.00 \mathrm{~g}$ & $13.33 \pm 0.19 \mathrm{e}$ \\
\hline Pioneer 29 flour & $4.67 \pm 0.19 e$ & $8.33 \pm 0.19 c$ \\
\hline Pertiwi 3 flour & $6.00 \pm 0.00 \mathrm{f}$ & $10.67 \pm 0.51 d$ \\
\hline Bisi 18 flour & $3.00 \pm 0.33 \mathrm{~d}$ & $6.00 \pm 0.33 b$ \\
\hline Bisma flour & $2.00 \pm 0.33 c$ & $6.33 \pm 0.19 b$ \\
\hline
\end{tabular}

Note: The mean at the same column followed by the same letters are not significantly different $(\mathrm{p}<0.05)$

Tabel 2. Mean number of Tribolium castaneum eggs on five corn varieties in whole grain and flour form in oviposition preference test

\begin{tabular}{|lc|}
\hline Treatments & $\begin{array}{c}\text { Mean number of eggs } \\
(\bar{X} \pm \text { SE })\end{array}$ \\
\hline Pioneer 21 whole grain & $7.67 \pm 1.02 \mathrm{a}$ \\
Pioneer 29 whole grain & $6.67 \pm 2.12 \mathrm{a}$ \\
Pertiwi 3 whole grain & $5.67 \pm 0.19 \mathrm{a}$ \\
Bisi 18 whole grain & $5.33 \pm 0.51 \mathrm{a}$ \\
Bisma whole grain & $6.67 \pm 1.26 \mathrm{a}$ \\
Pioneer 21 flour & $145.00 \pm 14.99 \mathrm{~d}$ \\
Pioneer 29 flour & $102.67 \pm 4.86 \mathrm{c}$ \\
Pertiwi 3 flour & $134.33 \pm 7.07 \mathrm{~d}$ \\
Bisi 18 flour & $79.00 \pm 4.16 \mathrm{bc}$ \\
Bisma flour & $70.33 \pm 5.59 \mathrm{~b}$ \\
\hline
\end{tabular}

Note: The mean at the same column followed by the same letters are not significantly different $(\mathrm{p}<0.05)$ 
Tabel 3. Mortality of Tribolium castaneum adults on five corn varieties in whole grain and flour form

\begin{tabular}{lc}
\hline Treatments & $\begin{array}{c}\text { Adult mortality* }(\%) \\
(\bar{X} \pm \text { SE })\end{array}$ \\
\hline Pioneer 21 whole grain & $1.11 \pm 0.64$ \\
Pioneer 29 whole grain & $6.67 \pm 1.11$ \\
Pertiwi 3 whole grain & $4.44 \pm 0.64$ \\
Bisi 18 whole grain & $10.00 \pm 2.94$ \\
Bisma whole grain & $5.56 \pm 3.21$ \\
Pioneer 21 flour & $1.11 \pm 0.64$ \\
Pioneer 29 flour & $1.11 \pm 0.64$ \\
Pertiwi 3 flour & $1.11 \pm 0.64$ \\
Bisi 18 flour & $6.67 \pm 2.22$ \\
Bisma flour & $2.22 \pm 1.28$ \\
\hline
\end{tabular}

Note: $*$ Data was transformed to $\sqrt{x+0,5}$

Based on the preference test, the mean number of $T$. castaneum adults female presence on Pioneer 21 flour was the highest (eight adults) and significantly different from others (Table 1). In contrast, the mean number of adults female presence on Pioneer 21 whole-grain was the lowest (one adult) and also significantly different than others, whereas the other four varieties i.e. Pioneer 29, Pertiwi 3, Bisi 18, and Bisma in whole grain form were not significantly different i.e. 1.33 adults. Total number of adults (male and female) presence was higher on Pioneer 21 flour (13.33 adults) than others varieties, while the lower presence was on Pioneer 29 and Pertiwi 3 whole grains (2.67 adults) and not significantly different with Bisi 18, Bisma, and Pioneer 21 in whole grain form at about $3.00,3.33$, and 3.67 adults, respectively, but it was significantly different with others (Table 1). The highest number of egg was on Pioneer 21 flour i.e. 145.00 eggs, however, it was not significantly different from Pertiwi 3 variety i.e., 134.33 eggs, but significantly different with others. On the other hand, the lowest number of eggs was on Bisi 18 whole-grain i.e., of 5.33 eggs, which was not significantly different with Pertiwi 3, Bisma, Pioneer 29, and Pioneer 21 varieties of whole-grain at $5.67 ; 6.67 ; 6.67$; and 7.67 eggs, respectively, but significantly different with others (Table 2). Astuti et al. (2013) stated that the preference of insects is influenced by physical and biochemical of grain. This result showed that T. castaneum was more preferred to colonize and oviposition in flour form of all varieties than whole-grain form. This was in line with Turaki et al. (2007), T. castaneum is a primary pest on processed grain like flour than other stored product in kernels. This insect was more preferred on flour form than whole grain (Abushama and Jerawi 1987; Zakka et al. 2013). Furthermore, the research results of Rustamani et al. (2014) showed that $T$. castaneum adults were more preferred on wheat flour (77\%) than semolina (19\%), corn kernels (2\%), and biscuit (2\%). The colonization preference of $T$. castaneum adults on feed indicates that the feed will be used as a host for copulation and laying eggs. The high number of eggs laid in the feed is related to the number of female adults present on the feed. The number of eggs was higher on Pioneer 21 flour because the present number of $T$. castaneum adult female was also higher on
Pioneer 21. There was a positive correlation between the number of $T$. castaneum adult females present with the number of eggs laid on the feed $(r=0.943 ; \mathrm{P}=0.01)$. The more number of adult females present on the feed, the more eggs laid on the feed.

\section{Population growth and development}

The statistical result on adult mortality was not significantly different on five corn varieties both in whole grain and flour form (Table 3). Results on the number of eggs, larvae, pupae, and F1 progeny emerged showed a significant effect on five corn varieties in whole grain and flour form (Table 4).

Table 4 showed that the highest number of eggs was on Pioneer 21 flour at about 196 eggs and not significantly different from Pertiwi 3 flour, but significantly different from others. On the contrary, the lowest number of eggs was on Bisi 18 whole-grain i.e., 11.00 eggs and not significantly different from another whole grain form of Pioneer 29, Pertiwi 3, and Bisma variety. Similarly, the highest number of larvae was on Pioneer 21 flour i.e., 179.67 larvae and the lowest was on Bisi 18 whole-grain which was not significantly different from Pioneer 29, Pertiwi 3, Bisma, and Pioneer 21 in whole grain. The highest number of pupae was on Pioneer 21 flour i.e., 83.67 pupae and not significantly different from Pertiwi 3 flour, while it was significantly different from others. The lowest number of pupae were found on Bisi 18 whole grain, and Pioneer 29, also were not significantly different from Pertiwi 3, Bisma, and Pioneer 21. The number of pupae result was as well as the number of F1 progeny emerged. The higher was on Pioneer 21 flour and not significantly different from Pertiwi 3 flour i.e. 73.33 and 64.00 adults, but it was significantly different from others. F1 progeny emerged on Bisi 18 and Pioneer 21 whole-grain was lower than another whole-grain variety form i.e. 1.00 adults (Table 4).

The developmental period of egg, larva, pupa, eggadult, and life cycle on five corn varieties in whole grain and flour form showed a significant influence. Egg period of T. castaneum was faster on Pioneer 21 flour i.e. 5.5 days and not significantly different from Pioneer 29 flour, Pertiwi 3 flour, and Pioneer 21 whole-grain, i.e. 5.67, 5.50, and 5.70 days, respectively. Egg period was experienced longer on Bisma whole grain at about 6.13 days and not significantly different from whole grain form of Bisi 18, Pertiwi 3, Pioneer 29 and flour form of Bisi 18 and Bisma. (Table 5).

The faster larval period was on Pioneer 21 flour at about 26.77 days and not significantly different from Pertiwi 3 flour at about 27.03 days. The longer period of larva was on Bisi 18 whole-grain i.e. 27.97 days which was not significantly different from other whole grain forms and significantly different from other flour forms. Similar to pupa, the faster period was found on Pioneer 21 flour i.e. 5.97 days which was not significantly different from Pertiwi 3 and Pioneer 29 flour i.e. 6.10 days. The longer period was on Bisma whole-grain i.e. 6.53 days and was not significantly different from all varieties in whole grain form, i.e. 6.43 days (Table 5). Developmental period of $T$. 
castaneum (egg-adults) was faster on Pioneer 21 flour at about 38.23 and not significantly different with Pertiwi 3 flour at about 38.63 days. On the contrary, it was longer on Bisma whole-grain, i.e. 40.63 days and not significantly different from Bisi 18 whole-grain, i.e. 40.23 days. Similarly, life cycle of $T$. castaneum experienced faster on Pioneer 21 flour which was not significantly different from Pertiwi 3 and Pioneer 29 flour at about 41.87, 42.73, and 42.77 days, respectively. The longer life cycle was on Bisma whole-grain i.e. 49.13 days and not significantly different from other varieties (Bisi 18, Pertiwi 3, and Pioneer 29) in whole grain form at about 48.57, 48.43, and 48.30 days, respectively (Table 5).
Table 7. The matrix of correlation coefficient between physicochemical characteristics of corn and the number of eggs, larvae, pupae, and F1 progeny emerged of Tribolium castaneum

\begin{tabular}{lcccc}
\hline $\begin{array}{l}\text { Physicochemical } \\
\text { characteristics }\end{array}$ & Eggs & Larvae & Pupae & $\begin{array}{c}\text { F1 progeny } \\
\text { emerged }\end{array}$ \\
\hline Protein & 0.258 & 0.291 & 0.363 & 0.399 \\
Fat & 0.005 & 0.023 & 0.021 & 0.014 \\
Ash & 0.108 & 0.094 & 0.146 & 0.173 \\
Water & 0.164 & 0.167 & 0.255 & 0.163 \\
Carbohydrate & -0.217 & -0.235 & -0.325 & -0.343 \\
Hardness & $-0.759^{*}$ & $-0.711^{*}$ & $-0.785^{*}$ & $-0.826^{*}$ \\
\hline
\end{tabular}

Note: * show significances

Tabel 4. Population growth of Tribolium castaneum eggs, larvae, pupae, and F1 progeny on five corn varieties in whole grain and flour form

\begin{tabular}{lcccc}
\hline \multirow{2}{*}{ Treatments } & \multicolumn{4}{c}{ Population growth $(\bar{X} \pm$ SE) } \\
\cline { 2 - 5 } & Number of eggs & Number of larvae & Number of pupae & F1 progeny \\
\hline Pioneer 21 whole grain & $25.67 \pm 1.71 \mathrm{~b}$ & $15.00 \pm 3.53 \mathrm{a}$ & $6.67 \pm 1.00 \mathrm{a}$ & $5.67 \pm 0.51 \mathrm{a}$ \\
Pioneer 29 whole grain & $15.00 \pm 3.28 \mathrm{ab}$ & $5.33 \pm 1.71 \mathrm{a}$ & $1.67 \pm 0.69 \mathrm{a}$ & $1.00 \pm 0.33 \mathrm{a}$ \\
Pertiwi 3 whole grain & $15.67 \pm 3.20 \mathrm{ab}$ & $5.67 \pm 1.02 \mathrm{a}$ & $2.67 \pm 0.69 \mathrm{a}$ & $2.33 \pm 0.84 \mathrm{a}$ \\
Bisi 18 whole grain & $11.00 \pm 0.67 \mathrm{a}$ & $3.67 \pm 1.71 \mathrm{a}$ & $1.67 \pm 0.51 \mathrm{a}$ & $1.00 \pm 0.33 \mathrm{a}$ \\
Bisma whole grain & $28.33 \pm 1.84 \mathrm{~b}$ & $18.33 \pm 1.20 \mathrm{a}$ & $7.00 \pm 0.51 \mathrm{a}$ & $4.67 \pm 0.51 \mathrm{a}$ \\
Pioneer 21 flour & $196.00 \pm 4.41 \mathrm{e}$ & $179.67 \pm 3.72 \mathrm{e}$ & $83.67 \pm 16.19 \mathrm{~d}$ & $73.33 \pm 15.08 \mathrm{~d}$ \\
Pioneer 29 flour & $137.00 \pm 5.86 \mathrm{~d}$ & $112.33 \pm 5.00 \mathrm{c}$ & $51.00 \pm 1.53 \mathrm{bc}$ & $39.00 \pm 1.15 \mathrm{bc}$ \\
Pertiwi 3 flour & $182.33 \pm 2.01 \mathrm{e}$ & $148.00 \pm 4.73 \mathrm{~d}$ & $75.67 \pm 10.86 \mathrm{~cd}$ & $64.00 \pm 13.04 \mathrm{~cd}$ \\
Bisi 18 flour & $120.33 \pm 4.02 \mathrm{~cd}$ & $91.67 \pm 3.50 \mathrm{~b}$ & $33.33 \pm 2.99 \mathrm{ab}$ & $25.33 \pm 1.84 \mathrm{ab}$ \\
Bisma flour & $107.00 \pm 3.00 \mathrm{c}$ & $81.00 \pm 2.52 \mathrm{~b}$ & $29.33 \pm 1.26 \mathrm{ab}$ & $23.67 \pm 1.95 \mathrm{ab}$ \\
\hline
\end{tabular}

Note: The mean at the same column followed by the same letters are not significantly different $(\mathrm{p}<0.05)$

Table 5. Developmental period of Tribolium castaneum on five corn varieties in whole grain and flour form

\begin{tabular}{lccccc}
\hline \multirow{2}{*}{ Treatments } & \multicolumn{4}{c}{ Developmental period (days) $(\bar{X} \pm$ SE) } \\
\cline { 2 - 6 } & Egg & Larva & Pupa & Egg-adult & Life cycle \\
\hline Pioneer 21 whole grain & $5.70 \pm 0.21 \mathrm{ab}$ & $27.83 \pm 0.05 \mathrm{e}$ & $6.43 \pm 0.02 \mathrm{c}$ & $39.97 \pm 0.08 \mathrm{ef}$ & $47.00 \pm 0.33 \mathrm{c}$ \\
Pioneer 29 whole grain & $5.83 \pm 0.08 \mathrm{bc}$ & $27.87 \pm 0.11 \mathrm{e}$ & $6.43 \pm 0.04 \mathrm{c}$ & $40.13 \pm 0.19 \mathrm{f}$ & $48.30 \pm 0.33 \mathrm{~cd}$ \\
Pertiwi 3 whole grain & $5.90 \pm 0.03 \mathrm{bc}$ & $27.73 \pm 0.04 \mathrm{de}$ & $6.43 \pm 0.07 \mathrm{c}$ & $40.07 \pm 0.14 \mathrm{f}$ & $48.43 \pm 0.19 \mathrm{~d}$ \\
Bisma 18 whole grain & $6.03 \pm 0.04 \mathrm{c}$ & $27.77 \pm 0.04 \mathrm{de}$ & $6.43 \pm 0.04 \mathrm{c}$ & $40.23 \pm 0.04 \mathrm{fg}$ & $48.56 \pm 0.38 \mathrm{~d}$ \\
Bisma whole grain & $6.13 \pm 0.05 \mathrm{c}$ & $27.97 \pm 0.04 \mathrm{e}$ & $6.43 \pm 0.05 \mathrm{c}$ & $40.63 \pm 0.13 \mathrm{~g}$ & $49.13 \pm 0.19 \mathrm{~d}$ \\
Pioneer 21 flour & $5.50 \pm 0.06 \mathrm{a}$ & $26.77 \pm 0.02 \mathrm{a}$ & $5.97 \pm 0.02 \mathrm{a}$ & $38.23 \pm 0.05 \mathrm{a}$ & $41.87 \pm 0.19 \mathrm{a}$ \\
Pioneer 29 flour & $5.67 \pm 0.08 \mathrm{ab}$ & $27.20 \pm 0.12 \mathrm{bc}$ & $6.10 \pm 0.03 \mathrm{ab}$ & $38.97 \pm 0.02 \mathrm{bc}$ & $42.73 \pm 0.19 \mathrm{a}$ \\
Pertiwi 3 flour & $5.50 \pm 0.03 \mathrm{a}$ & $27.03 \pm 0.05 \mathrm{ab}$ & $6.10 \pm 0.03 \mathrm{ab}$ & $38.63 \pm 0.02 \mathrm{ab}$ & $42.77 \pm 0.19 \mathrm{a}$ \\
Bisi 18 flour & $5.83 \pm 0.04 \mathrm{bc}$ & $27.23 \pm 0.02 \mathrm{bc}$ & $6.17 \pm 0.02 \mathrm{~b}$ & $39.23 \pm 0.04 \mathrm{~cd}$ & $44.20 \pm 0.00 \mathrm{~b}$ \\
Bisma flour & $5.83 \pm 0.05 \mathrm{bc}$ & $27.50 \pm 0.00 \mathrm{~cd}$ & $6.20 \pm 0.03 \mathrm{~b}$ & $39.53 \pm 0.02 \mathrm{de}$ & $45.50 \pm 0.33 \mathrm{~b}$ \\
\hline
\end{tabular}

Note: The mean at the same column followed by the same letters are not significantly different $(\mathrm{p}<0.05)$

Table 6. Grain characteristics of five corn varieties

\begin{tabular}{|c|c|c|c|c|c|}
\hline \multirow{2}{*}{ Physicochemical characteristics } & \multicolumn{5}{|c|}{ Corn varieties } \\
\hline & Pioneer 21 & Pioneer 29 & Pertiwi 3 & Bisi 18 & Bisma \\
\hline Protein $(\%)$ & 8.86 & 6.99 & 8.83 & 6.88 & 6.48 \\
\hline Fat $(\%)$ & 4.44 & 4.99 & 3.83 & 3.45 & 4.64 \\
\hline Water $(\%)$ & 12.11 & 12.97 & 14.65 & 10.78 & 9.45 \\
\hline Ash (\%) & 1.26 & 1.18 & 1.37 & 1.21 & 1.30 \\
\hline Carbohydrate $(\%)$ & 73.33 & 73.87 & 71.32 & 77.68 & 78.13 \\
\hline Hardness level & 277.36 & 401.80 & 275.17 & 403.14 & 262.46 \\
\hline
\end{tabular}


Preference, growth, and development of T. castaneum is influenced by physical and chemical factors. The physical factors that affect preference, growth, and development of $T$. castaneum are the form and the hardness of feed, while the chemical factors are feed nutrition and volatile compound on feed. The physical forms of feed used in this study were whole grain and flour, and the chemical aspect tested was proximate analysis. This study revealed a negative correlation between the grain hardness and the number of eggs $(r=-0.759)$, the number of larvae ( $r$ $=-0.711)$, the number of pupae $(r=-0.785)$, and the number of F1 progeny emerged ( $\mathrm{r}=-0.826)$ (Table 7). These results mean that the softer grain resulting in the more insect growth. Corn seeds that have high hardness levels can inhibit $T$. castaneum adults and larvae feeding activity. The higher hardness of corn seeds will express the lower number of eggs, larvae, pupae, and F1 progeny emerged. Astuti et al. (2013) stated that the hardness level of seeds was negatively correlated to the number of eggs and F1 progeny emerged of Rhyzopertha dominica. This resulting study showed that Bisi 18 was less preferred by $T$. castaneum because it has higher hardness levels than others i.e. 403.14 (Table 6).

Tribolium castaneum more preferred to feed and lay eggs on high nutritional quality of feeds (Abushama and Jeraiwi 1987; Bostan and Naeem 2002; Javed et al. 2016). The low nutritional quality of feed can inhibit some insect activities especially for feeding and laying eggs to support the growth and development of $T$. castaneum (Turaki et al. 2007; Chapman 2013). However, there was no correlation found between protein, fat, ash, water, and carbohydrate content with the number of eggs, larvae, pupae, and F1 progeny emerged. This indicated that the chemical content on various types of varieties did not affect the preference level of $T$. castaneum. This insect was more preferred with the physical characteristic of feed, not only the form but also the hardness of kernels. Pioneer 21 corn variety has higher protein content than Pioneer 29, Pertiwi 3, Bisi 18, and Bisma (Table 6). This showed that protein content on feed affected the preference, growth, and development of $T$. castaneum insects. High protein content on feed causes greater preference, growth, and development of $T$. castaneum insects compared to the feed which has low protein content. This was in accordance with Khair (2002), Kayode et al. (2014), and Sarwar (2015) that stated the preferences, growth, and development of $T$. castaneum insects are greater on high protein content feed. Furthermore, a report by Wong and Lee (2011) show that adult beetles of $T$. castaneum more emerged on the high protein content diet, however, it was fewer number of adult and longer adult development on high carbohydrate content diet because it may be toxic.

The highest population growth of $T$. castaneum was on Pioneer 21 flour, even though adult insect mortality was not significantly different among all treatments. This indicated that $T$. castaneum still could feed on whole grain though it was more difficult than on corn-flour. In addition, Zakka et al. (2013) also stated that adult mortality of $T$. castaneum was not significantly different in both whole grain and flour form, but the population growth of this insect was higher on flour form.

In conclusion, the highest preference, population growth, and development of T. castaneum are on Pioner 21 variety in flour form. The most influential factor of its preference and biology is the physical characteristics both in form and hardness level of kernels. However, the chemicals content of different varieties in the same type of commodity does not affect the preference, population growth, and development of $T$. castaneum.

\section{ACKNOWLEDGEMENTS}

Authors would like to thank our colleagues Akhmad Rizali for linguistic assistance during the preparation of this manuscript.

\section{REFERENCES}

Abushama FT, Jeraiwi JA. 1987. Food preference and development on the red flour beetle Tribolium castaneum (Herbst), a major pest of stored grain in Kuwait. J Univ Kuwait (Sci) 14: 160-172.

Astuti LP, Mudjiono G, Rasminah ChS, Rahardjo BT. 2013. Susceptibility of milled rice varieties to the lesser grain borer (Rhyzopertha dominica F.). J Agric Sci 5: 145-149.

Beeman RW, Haas S, Friesen K. 2019. Beetle wrangling tips (an introduction to the care and handling of Tribolium castaneum. United States Department of Agriculture (USDA), Agricultural Research Services (ARS), Washington DC.

Bennett SM. 2003. Life cycle Tribolium confusum (confused flour beetle) and Tribolium castaneum (rust-red flour beetle). The University of Texas at Austin, Austin, https://web.ma.utexas.edu/users/davis/375/LECTURES/L2/Tribolium.pdf

Bostan N. Naeem M. 2002. Evaluation of resistance in some wheat cultivar of Tribolium castaneum (Herbst) under laboratory condition. J Plant Sci 1: 95-98.

Campbell JF, Hagstrum DW. 2002. Patch exploitation by Tribolium castaneum: movement patterns, distribution and oviposition. J Stored Prod Res 38: 55-68.

Campbell JF, Runnion C. 2003. Patch exploitation by female red flour beetles, Tribolium castaneum. J Insect Sci 3: 1-8.

Chapman RF. 2013. Nutrition. Revised by Simpson SJ, Douglas AE. The Insects, Structure and Function (5th ed.). Cambridge University Press, New York.

Fedina TY, Lewis SM. 2007. Effect of Tribolium castaneum (Coleoptera: Tenebrionidae) nutritional environment, sex, and mating status on response to commercial pheromone traps. J Econ Entomol 100: 19241927

Heinrichs EA, Medrano FG, Rapusas HR. 1985. Genetic Evaluation for Insect Resistance in Rice. International Rice Research Institute (IRRI), Los Banos, Philippines.

Javed M, Majeed MZ, Khaliq A, Arshad M, Ahmad MH, Sufyan M. 2016. Quantitative losses in some advanced genotypes of barley incurred by Tribolium castaneum L. (Herbst). Intl J Agron Agric Res 8: 45-50.

Kayode OY, Adedire CO, Akinkurolere RO. 2014. Influence of four cereal flours on the growth of Tribolium castaneum Herbst (Coleoptera: Tenebrionidae). Ife J Sci 16: 505-516

Khair ASM. 2002. Studies on the Biology of the Red Flour Beetle Tribolium castaneum Herbst (Coleoptera: Tenebrionidae) in Different Cereal Flour. [Thesis]. University of Khartoum, Sudan

Khawar J, Ata Z, Farooq M. 2007. Maize: Cereal with a Variety of Uses. DAWN Business. http://wwwdawn.com/2007/03/12/ebr5.htm

McDonald G, Meylinah S. 2019. Indonesia Grain and Feed Annual Report 2019. Global Agricultural Information Network. USDA Foreign Agricultural Services, New York.

Oladejo JA, Adetunij MO. 2012. Economic analysis of maize (Zea mays I.) production in Oyo State of Nigeria. Agricult Sci Res J 2: 77-83. 
Rees D. 2004. Insect of Stored Products. CSIRO Publishing, Australia. Rustamani MA, Khatri I, Sultana R, Laghari MH. 2014. Population fluctuation of red flour beetle, Tribolium castaneum (Herbst) (Coleoptera: Tenebrionidae) on different cereal foods in laboratory. J Zool 46: 1511-1514

Sarwar M. 2015. Categorization of some advanced local wheat lines Tribolium castaneum (Herbst) (Coleoptera: Tenebrionidae). Intl J Life Sci Eng 1: 108-113.

Statistics Indonesia. 2019. Production of Maize by Province (ton). 1993 2015. BPS,

Jakarta

https://www.bps.go.id/dynamictable/2015/09/09/868/produksijagung-menurut-provinsi-ton-1993-2015.html. [Indonesian]

Suleiman R, Kurt R. 2015. Current maize production, post-harvest losse and the risk of mycotoxins contamination in Tanzania. Agricultura and Biosystems Engineering Conference Proceedings and
Presentations. Iowa State University, New Orleans, Louisiana, 26-29 July 2015.

Swastika DK, Firdaus SK, Wayan S, Rachmat H, Kecuk S, Roberta VG, Prabhu LP. 2004. Maize in Indonesia. Production Systems, Constraints, and Research Priorities. CIMMYT, Mexico.

Turaki J, Sastawa MBM, Kabir BGJ, Lale NES. 2007. Susceptibility of flours derived from various cereal grains to infestation by the rust-red flour beetle (Tribolium castaneum Herbst) (Coleoptera: Tenebrionidae) in different seasons. J Plant Prot Res 47: 279-288.

Wong N, Lee CY. 2011. Relationship between population growth of the red flour beetle Tribolium castaneum and protein and carbohydrate content in flour and starch. J Econ Entomol 104: 2087-2094.

Zakka U, Lale NES, Duru NM, Ehislanya CN. 2013. Response of chips and flour from four yam varieties to Tribolium castaneum (Herbst) (Coleoptera: Tenebrionidae) infestation in storage. Afr J Agric Res 8: 6629-6633. 